\title{
VENE-EESTI KOODIVAHETUSE FUNKTSIOONID KOHTLA-JÄRVE VENEKEELSETE LASTE VESTLUSES
}

\section{Anastassia Zabrodskaja}

Ülevaade. Vene-eesti koodivahetus on loomulik nähtus Kohtla-Järve noorte seas. Artiklis on vaatluse all vene emakeelega laste kakskeelsed dialoogid Peter Aueri pragmaatilis-konversatsioonilise mudeli valguses. Eesmärgiks on noorte argikõnes esinevate pragmaatiliskonversatsiooniliste funktsioonide selgitamine, kusjuures grammatilised aspektid ei ole täiesti kõrvale jäetud. Informantideks on vene ja eesti keelt kõnelevad õppurid, kellelt on keeleainest kogutud sundimatus olukorras.

Võtmesõnad: koodivahetus, diskursiivne vahend, pragmaatilis-konversatsiooniline mudel, pragmaatilis-konversatsiooniline funktsioon, vestlusanalüüs, eesti keel, vene keel

\section{Koodivahetuse funktsioonidest mujal ja meil}

Vestlus moodustab inimeste kommunikatsiooni peamise osa, mille käigus hakkavad lapsed suhtlema, vahetades kõneregistreid ja -stiile (Ervin-Tripp 2001). Suhtlemisel on mitmeid funktsioone: info vahetamine, oma eesmärgi saavutamine, sotsiaalsete suhete kindlustamine, emotsionaalse seisundi väljendamine jne (Kalliokoski 1989, Duranti 1991, Duranti, Goodwin 1993). Igas ametlikult kakskeelses kogukonnas vahetatakse koodi dialoogi vältel (Romaine 2000: 2), kuigi koodivahetuse esinemissagedus ja funktsioonid on eri juhtudel erinevad.

Nii sotsiolingvistide kui ka psühholoogide eriliseks huviobjektiks on jäänud kakskeelsete kõnelejate võime vahetada keelt vestluse erinevates kohtades. Neid huvitab, miks teatud hetkel toimub vestluses koodivahetus ning kes koodi vahetab. Ainult et uurimismeetodid ja vaatluse tasandid on erinevad.

Enamik esimesi empiirilisi koodivahetusuurimusi käsitleb täiskasvanu-vestleb-täiskasvanuga-mudelit (Clyne 1967, Gumperz 1967, 1973, Weinreich 1966). 
Shana Poplack (1980) analüüsib oma klassikalises töös Puerto Rico kakskeelsete täiskasvanute vestlusi loomulikus ümbruses ja nende kõnet sotsiolingvistilise intervjuu käigus, et rohkem uurida kakskeelsete lingvistilist pädevust ja koodivahetamist. S. Poplack (1980) ja Ana-Celia Zentella $(1982,1997)$ leiavad, et koodi vahetavad inimesed ja lapsed, kes on tasakaalus kakskeelsed (fluent and balanced in both languages). Koodivahetuse konversatsioonianalüüsi seisukohalt võib koodivahetus samuti korraga hõlmata rohkem kui üht funktsiooni (Gumperz 1982a: 97, Auer 1992: 32, Li 1995, Kalliokoski 1995, Stroud 1998).

1970. aastate teisel poolel hakati huvi tundma ka laste koodivahetuse vastu (Álvarez 1979, Genishi 1976, Zentella 1982, 1997). Need uurijad on püüdnud selgitada, kuidas mõlemad keeled enam-vähem samal ajal omandanud lapsed (simultaneous bilinguals) vahetavad koodi sõltuvalt adressaadist ja kontekstist.

Kui täiskasvanute koodivahetus näitab kakskeelsuse astet ${ }^{1}$ (Poplack 1980), siis keelt õppivatel lastel võib see olla ka kakskeelse kommunikatiivse pädevuse arengu ilming (Reyes 2001). Ei ole aga kirjeldatud, kuidas laste koodivahetus aja jooksul areneb, samuti ei ole uuritud, kuidas toimib koodivahetus kommunikatiivse pädevuse osana eakaaslaste vestluses, kui tahetakse saavutada mingit eesmärki.

Mingi keele kõnelejad on võimelised vahetama registreid (Gumperz 1967, Ervin-Tripp 1964, 2001). Samad võtted on olemas ka kakskeelsetel, kuid lisanduvad veel eri keeled. Keelt vahetatakse vestluse käigus sotsiolingvistiliste strateegiate rakendamise eesmärgil. Teiste sõnadega, kõneleja soovib ennast väljendada just koodivahetuse kaudu. Koodivahetuse funktsioone võib olla mitmeid. Pakutakse erinevaid variante, neis leidub ka kokkulangevusi. Kõige rohkem peavad uurijad koodivahetust ajendavateks teguriteks vestluse adressaate, olukorda ja kaasvestlejate sotsiaalseid rolle (E. McClure, M. McClure 1988). Samas leitakse, et teemavahetus, aga ka ühe keele eelistamine või välistamine võib vahetamist soodustada.

François Grosjean (1982: 152), René Appel ja Pieter Muysken (1992: 118120), Colin Baker (1995: 77) ning P. Auer (1995: 120) on koostanud loendeid põhilistest pragmaatilis-konversatsioonilistest funktsioonidest, mis kaasnevad ühelt keelelt teisele üleminekuga. Tabeli 1 ridadel on püütud ühendada eri käsitluste sarnased ja lähedased koodivahetuse funktsioonid.

Igas konkreetses sotsiolingvistilises situatsioonis võivad lisanduda muudki (nt kõnelejast põhjustatud) tegurid, mis pole koodivahetuse uurijale ette teada. Koodivahetus saab esineda ka teise keele õppimise strateegiana (second-language learning strategy) (Arnfast, Jørgensen 2003). C. Baker (1995: 77) märgib omakorda, et koodivahetusel ei saa olla ainult lingvistilisi aspekte. Rolli mängivad ka sotsiaalsed ja psühholoogilised põhjused, keeltevahelised võimusuhted, tegu võib olla keele ja murde koodivahetusega. Koodivahetuse sotsiopsühholoogilistest eripäradest kirjutab nt Carol Myers-Scotton (1993).

Huvitav on asjaolu, et kõnelejad ise ei oska oma võimet koodi vahetada iseloomustada (vt nt Herbert 2001). Kõige tavalisem vastus on: "Ma lihtsalt teen niimoodi." Samas aga väidetakse, et loomupäraseim on koodivahetus just vestlustes tuttavate, kolleegide või sugulastega. S. Poplack (1988: 240) aga rõhutab, et vaatamata kakskeelsele keelekogukonnale leidub alati neid, kes ei vaheta koodi.

${ }^{1}$ Tegelikult võib koodi vahetada isegi vähese keeleoskuse korral (Auer 1999), niisiis pole koodivahetus otseselt kakskeelsuse taseme näitaja. 
Tabel 1. Koodivahetuse funktsioonid viie autori käsitluses

\begin{tabular}{|c|c|c|c|}
\hline C. Baker & F. Grosjean & $\begin{array}{l}\text { R. Appel, } \\
\text { P. Muysken }\end{array}$ & P. Auer \\
\hline $\begin{array}{l}\text { sotsiaalsete/ } \\
\text { etniliste piiride } \\
\text { ületamine }\end{array}$ & $\begin{array}{l}\text { adressaadi } \\
\text { täpsustamine }\end{array}$ & $x$ & topikalisatsioon \\
\hline$x$ & $\begin{array}{l}\text { usalduse, viha, } \\
\text { pahameele } \\
\text { väljendamine }\end{array}$ & $\begin{array}{l}\text { ekspressiivne } \\
\text { funktsioon }\end{array}$ & $x$ \\
\hline$x$ & $\begin{array}{l}\text { kõneleja isikliku huvi } \\
\text { markeerimine }\end{array}$ & & $x$ \\
\hline & $x$ & keelemäng & \\
\hline & $x$ & kommentaar & \\
\hline $\begin{array}{l}\text { kordamine } \\
\text { selguse nimel }\end{array}$ & \multicolumn{2}{|c|}{$x$} & kvaasitõlge \\
\hline \multicolumn{2}{|c|}{ leksikaalse lünga täitmine } & $\begin{array}{l}\text { ühe keele ebapiisav } \\
\text { oskus }\end{array}$ & $x$ \\
\hline$x$ & rääkija rolli muutmine & $x$ & rollivahetus \\
\hline $\begin{array}{l}\text { vestluse pinge } \\
\text { vähendamine }\end{array}$ & $x$ & $\begin{array}{l}\text { vestluse } \\
\text { tempo/tooni } \\
\text { muutmine }\end{array}$ & $x$ \\
\hline \multicolumn{2}{|c|}{$\begin{array}{l}\text { rühma markeerimine, rühma poolt } \\
\text { omaksvõtmine }\end{array}$} & $x$ & $\begin{array}{l}\text { osalejaskonna } \\
\text { muutus }\end{array}$ \\
\hline mõtte rõhutamine & $\begin{array}{l}\text { sõnumi rõhutamine/ } \\
\text { toonitamine }\end{array}$ & \multicolumn{2}{|r|}{$x$} \\
\hline tsitaat & & $x$ & tsitaat \\
\hline \multicolumn{3}{|c|}{ vestlusesse kaasamine/vestlusest kõrvaldamine } & $x$ \\
\hline \multicolumn{3}{|c|}{$x$} & teemavahetus \\
\hline $\begin{array}{l}\text { väljendi } \\
\text { lihtsustamine/ } \\
\text { tõhustamine }\end{array}$ & \multicolumn{3}{|c|}{$x$} \\
\hline$x$ & $\begin{array}{l}\text { viimase keele } \\
\text { kasutamise jätkamine }\end{array}$ & & $x$ \\
\hline
\end{tabular}


Varasemates pragmaatilistes uurimustes on sõnastatus koodivahetuse tüübid ja seda mõjutavad faktorid (Ervin-Tripp 1964, Fishman 1965, Gumperz 1964, 1967, Clyne 1967, Gumperz, Hernández-Chavez 1975). Nimelt varieerub koodivahetus sõltuvalt situatsioonist ja vestluse eesmärgist. Viimase puhul eristatakse veel funktsioone diskursusest lähtudes: vestlusesse kaasamine või vestlusest kõrvaldamine, intiimsuse väljendamine, sõnumi toonitamine jne.

Laste koodivahetuse uurimused näitavad, et lapsed, kes on kakskeelsed sünnist saadik, arendavad oskust vahetada keelt sõltuvalt adressaadist, vestluse teemast ja situatsioonist (Genishi 1976, McClure 1981, Fantini 1985, Halmari, Smith 1994, Zentella 1982, 1997). Fred Genesee ja tema kolleegid leiavad oma hilisemates töödes (Genesee jt 1996, Genesee 2002), et 2-aastased prantsuse-inglise kakskeelsed lapsed proovivad kasutada ja kohandada mõlemat keelt teadlikult vaheldades vanemate ja võõraste vestluskaaslastega. See oskus on nende kommunikatiivse kompetentsi osa. F. Genesee (2002: 174) läheb veel kaugemale ja nendib, et tõeline kakskeelne kommunikatiivne pädevus nõuab oskust mugandada keelekasutust vastavalt reaalse situatsiooni asjakohastele tingimustele, arvestades kaasvestleja keelevalikuga.

Noorte hispaania-inglise bilingvaalidega läbiviidud katsete tulemused näitavad, et väiksemad lapsed kasutavad rohkem ühesõnalisi koodivahetusi kui vanemad lapsed (McClure 1981, Zentella 1997). Tavaliselt seletatakse seda nähtust sellega, et ebapiisava keeleoskuse tõttu vahetavad lapsed koodi leksikaalse lünga täitmiseks. Ülle Rannut (2003: 19) kirjutab koodivahetusest kui loomulikust nähtusest kakskeelsete laste kõne arengus. Tema arvates on see mööduv nähtus, mis iseloomustab teise keele õppijate vahekeelt, mis on tingitud siht- või emakeelsete vastete mitteteadmisest, üksnes keeleõppe algusfaasis. Claus Færch, Kirsten Haastrup ja Robert Phillipson (1984: 164) väidavad, et koodivahetuse strateegiat kasutavad õppijad ainult keele omandamise algfaasis. Põhimõtteliselt pole see vale (vt Zabrodskaja, ilmumas), kuid on tõendeid selle kohta, et algaja keeleõppija võib vahetada koodi täpselt samadel pragmaatilistel eesmärkidel nagu vilunud kakskeelne inimene (Arnfast, Jørgensen 2003). Samal ajal on selgunud, et vanemad lapsed käsitsevad keeli erinevate stilistiliste eesmärkide täitmiseks ja situatsioonile sobitamiseks osavamalt kui nooremad (Zentella 1997).

Tehes katseid türgi-taani kakskeelsete lastega, leiab Normann Jørgensen (1998), et 7- ja 10-aastased opereerivad kahe keelega võimusuhete väljendamiseks. Selles uurimuses võitlevad lapsed vestluse kontrollimise eest, kui tegu on probleeme lahendavate ülesannetega.

Mõned uurijad kinnitavad, et vanemad lapsed hakkavad vahetama koodi, kui saavad aru, et teise keele elemendid väljendavad teatud mõistet täpsemalt (Halmari, Smith 1994, Zentella 1997).

Võib siiski väita, et siiamaani ei ole kindlaks tehtud, kuidas arenev kakskeelne laps lihvib aja jooksul oma oskust vahetada koodi ja kuidas ta kasutab oma eakaaslastega suhtlemisel koodivahetust kommunikatsioonistrateegiana.

Maailma eri kohtades tehtud uuringud on näidanud, et noored kakskeelsed vahetavad koodi palju rohkem, kui nende vanemad ja vanavanemad. Üks hispaania-inglise kakskeelne nooruk vastas uurija küsimusele hispaania ja inglise keele vaheldamise põhjustest (Koziol 2000: 12): 
With my grandmother, I almost always speak Spanish .. [with] my parents, it is usually one or the other [Spanish or English] .. but mis primos y mis amigos, we speak both all the time. I don't know why.. It's how we talk. 'Oma vanaemaga räägin põhiliselt hispaania keeles .. [oma] vanematega kas üht keelt või teist .. aga oma parimate sõpradega meie kõneleme mõlemat keelt. Ma ei tea, miks .. See on nii, kuidas meie räägime.'

Seda võib väita ka Kirde-Eesti laste kohta, kes kasutavad eesti keelt aeg-ajalt suhtlemiseks, kuigi Kohtla-Järve on rahvusliku koosseisu poolest spetsiifiline linn (2/3 elanikkonnast on venekeelsed, vt Vseviov 2002), kakskeelne kõne ei tekita võõristust ja on täiesti loomulik omavahelises suhtluses (vt Zabrodskaja 2004).

Käesolevas artiklis vaadeldakse Kohtla-Järve laste vene-eesti koodivahetust pragmaatilis-konversatsioonilise mudeli (Auer 1995) seisukohalt. Pragmaatilise lähenemise rajaja on John Gumperz (Blom, Gumperz 1972), kes on jaotanud koodivahetuse situatiivseks (situational code-switching) ja metafooriliseks (metaphorical code-switching). Esimene johtub vestlussituatsiooni muutusest (nt veel ühe kaasvestleja ilmumine), teine mängib kommentaari rolli. Hilisemates töödes käsitleb J. Gumperz (1982a, b) koodivahetust kui kontekstualiseerimise vihjet (contextualization cue): see kannab pragmaatilist ja sotsiaalset informatsiooni täpselt samuti nagu žestid, intonatsioon, paus, kõhklus, rõhutamine jms. Lähtepunktiks on koodivahetuse funktsioon vestluses. Tema järelkäijad on Robert Le Page ja Andrée Tabouret-Keller (1985) ning P. Auer (1984, 1992, 1995, 1999). J. Gumperzi arusaam (1982a, b, 1993) kontekstualiseerimise vihjest on rajatud tähelepanekule, et vestluspartnerid asuvad pidevalt mitmest aspektist muutuvas kontekstis, mida nad on võimelised kajastama oma kõnes. Sellele faktile toetub ka koodivahetuse pragmaatilis-konversatsiooniliste funktsioonide analüüs. J. Gumperz (1982a) ja P. Auer (1984, 1992, 1998) rõhutavad, et koodivahetus on peamiselt diskursiivne vahend (discourse device) koos erinevate funktsioonidega. Seega on igati loogiline analüüsida koodivahetuse pragmaatilis-konversatsioonilisi funktsioone, välistades sellise teguri nagu keeleoskuse tase. P. Auer väidab, et kakskeelses suhtluses eelistatakse alati üht keelt kuni olukorra muutumiseni, mille järel toimub üleminek teisele keelele. P. Auer teeb vahet diskursusega seotud ja osavõtjaga seotud keele vahetuse vahel. Tema arvates ei pruugi konkreetne tegevus alati põhjustada keele vahetust (Auer 1984, 1998).

Siinses artiklis käsitletavad näited on kuuldud argielus (suvised koolilaagrid, isiklikud kontaktid) ning kirja pandud käsitsi. Sellel metoodilisel võttel on ehk oma puudusi (kui vestlus on lindistatud, siis saab kuulata mitu korda, leides aina uusi nüansse). Samas väidavad aga Ameerika juutide keele uurijad Leonard Plotnicov ja Myrna Silverman (1990: 92), et nende uurimuse nõrgaks küljeks osutus just Labovi sõnastatud "vaatleja paradoks" (participant observation): "Kuna meie ei olnud kogukonna liikmed, siis vaevalt saime fikseerida just loomulikke vestlusi."

Paljud funktsioonid tabelist 1 leiduvad Kohtla-Järvelt kogutud keeleaineses. Uurimus on rõhutatult kvalitatiivne ja eesmärgiks on eelkõige nähtuste kaardistamine, seepärast ei tegelda vene-eesti koodivahetuse võimalike struktuuripiirangute väljaselgitamisega.

Kogutud materjalis esineb vene-eesti koodivahetus fraaside/lausete sees (intrasentential code-switching) või fraaside/lausete vahel (extrasentential code- 
switching). Enamasti jäävad eestikeelsed fraasid laste omavahelises vestluses lühikeseks, eesti sõnu lihtsalt sisestatakse venekeelsetesse repliikidesse. See tähelepanek osutab faktile, et need on rohkem sisestava vahetuse (insertion) näited (Muysken 2000: 3-10).

\section{Keelemäng}

Koodivahetus on kahtlemata pragmaatiline nähtus (olles samuti grammatiline, psühholingvistiline jm nähtus). Kõneleja soovib endale tähelepanu tõmmata oma ekspressiivsuse, omapärasusega. Sellega peab eriti arvestama, kui kõne all on lapsed. F. Grosjean (1982: 206-207) näitab, et kakskeelsed lapsed kipuvad "mängima" keelega ja teadlikult vahetavad koodi, taotledes koomilist efekti. Niisugune koodivahetus ei nõua mõlema keele põhjalikku oskust. Isegi lapsed, kes alles alustavad teise keele õppimist, võivad kasutada sama tehnikat (Romaine 2000: 227-236).

\subsection{Spontaanne loovus}

Vahel toimub keelemäng spontaanselt ja keegi kaasvestlejatest mängib keelega juba teadlikult, nagu näidetes (1-4).

(1) Lapsed (P1 ja P2) vestlevad vaikselt omavahel. (Kohtla-Järve Pärna Põhikool, 4. klass, juuni 2004)

P1: За этот пери 'оoд. 'Selle perioodi jooksul'

P2: За какой перевод? 'Millise tõlke eest?'

P1: Пери `оод, ой пер 'иод. 'Periood, oh periood'

P2: Перивод, перивод! Vigane kombinatsioon sõnadest период 'periood' jа перевод 'tõlge'

Vene keeles on rõhk sõnas период 'periood' teisel silbil. Eesti keeles on see võõrsõna periood ja rõhk on viimasel silbil. P1 hälaldab eesti moodi, rõhutades viimast silpi. See tuleb tal välja venekeelse sõnaga перевод 'tõlge' sarnaselt. Teine poiss ei saa algselt aru, millest on jutt. Kui aga saab, siis hakkab sõnaga mängima.

(2) Üks poiss (P1) ei leia oma eestikeelseid raamatuid. Hõiskab:

$\mathrm{P} 1$ : Где raamatut? 'Kus on raamatud?'

P2: Raamat tut. 'Raamat on siin'

Taoline keelemäng on põhjustatud kahe keele sõnade osalise foneetilise kuju kattumisest. Vrd

ee raamatud $<$ raamat + -ud

vn raamat tut 'raamat on siin'

kv ee raamat + vn tut 'siin' 
(3) Pärast eesti keele tundi, mis on tunniplaani järgi viimane, vestlevad kaks poissi (P1 ja P2) omavahel. (Kohtla-Järve Pärna Põhikool, 3. klass, veebruar 2004.)

P1: Lähme koju! 'Lähme koju!'

Р2: Нет. Ты lähemai, а я побуду ещё в rühme до трёх. Мама поздно дома будет. 'Ei. Mine ise, aga mina jään (pikapäeva)rühma kella kolmeni. Ema tuleb hilja koju.’

Verbi vorm lähemai on kindlasti loovuse näide, sest see ei vasta ei eesti ega vene grammatika reeglitele.

(4) Õpilased jalutavad metsas. Metsas on palju lilli. Üks esimese klassi ôpilane (P1) ütleb (Kohtla-Järve 3. Keskkooli suvine keelelaager, juuni 2000, lapsed on algklasside õpilased):

P1: Как здесь красиво! 'Siin on nii ilus!'

P2 (lisab): И так много lilledov! 'Ja nii palju lilli!'

Võib oletada, et koodivahetuse esinemissagedust tugevdab ka vene laste emotsionaalne keeleline käitumine. Eri maades tehtud uurimused on kinnitanud tulemust, et venelased kasutavad üldiselt rohkem standardile (ametlikule vene keele normile) mittevastavaid vorme ja konstruktsioone, mis on seotud nn prostorečijega (ehk argise harimatu kõne registriga, kus on ka mõningaid murdejooni). Anna Wierzbicka (1999: 216-240) näitab, kuidas venelaste keel varieerub vastavalt selle kasutusele erinevates suhtlussituatsioonides.

\subsection{Nimemäng}

Huvitav nähtus on mängimine vene nimedega, mis langevad kokku eesti keele sõnadega. (Kohtla-Järve 3. Keskkooli suvine keelelaager, juuni 2000, lapsed on algklasside õpilased.)

(5) Anna mulle.

Iga eesti emakeelekõneleja jaoks kõlab see lause, kui palve midagi anda/ulatada jne. Samas on Anna ka rahvusvahelise levikuga tüdrukunimi, mis on olemas nii eesti kui ka vene keeles. Kui Anna-nimelise tüdruku poole pöördutakse "Anna mulle”, siis see ei tähenda midagi muud kui nimi “Anna”. Seejuures võib ta oma kaasvestlejale vastata nt "Ahaa, Leena [nimetab pöördujat eesnime järgi] sulle”. Sama kehtib ka nimede Niina ja Katja puhul. Niina puhul otsitakse alati nina.

(6) $A$ где Nina? 'Kus on Niina?' [tavaliselt tullakse sellise küsimusega tüdruku juurde ja võetakse ta ninast kinni]

Vene nimi Nina (mitte eestipärane Nïna) kõlab nagu eesti nina, millele omakorda vastab vene keeles нос 'nina'.

Katjal aga ei vedanud üldse, temal oli alati midagi "katki”.

(7) У Катьки ручка [või ükskõik mis] katki. 'Katkal on pastakas katki.' 
Näites (7) on y Катьки [u Katki] käändevorm nimest Katka. Vrd

vn Катя - Катька - у Катьки. 'Katja - Katka - u Katki'

ee Katja - Katka - Katkal

\subsection{Deminutiivnimemäng}

Kohtla-Järve 3. Keskkooli suvine keelelaager, juuni 2000, lapsed on algklasside õpilased.

(8) Oleme ekskursioonil Toilas, üks esimese klassi õpilane ütleb pärast pikka jalutamist mööda parki:

“Я так проголодался. Вот бы сейчас võileibčik съесть.” 'Mul on kõht tühi. Tahaks võileivakest süüa.'

(9) Hommikusöök oli juba ammu alanud, kui üks õpilane tormas kööki. Oli näha, et ta kiirustas, et ei jääks väga hiljaks. Õpetaja ütleb:

"Noh, miks sa hilinesid? Mis sinuga täna juhtus?” Õpilane ei jõudnud veel vastata. Teine aga kommenteerib: “А он у нас unimütsik.” 'Tema on meil unimütsikene.'

(10) 4. klassi õpilased astuvad 1. klassi ruumi. Keegi ütleb: "Ну и tooliki [hääldatud normaalse pika $o$-ga]”. 'On alles toolikesed!'

\subsection{Kolmkeelne mäng}

Näites (11) sisalduv koodivahetuslik küsimus “Сегодня kes on on duty?” sisaldab tervelt kolme keele elemente ning meenutab kolmkeelsete täiskasvanute suhtlusvõtteid. Kuna kõnelejal ei ole võimalust planeerida ja parandada oma lauseid, on loomulik, et mõni sõna, tarind, sõnaühend vms allub kahe või kolme keele normingutele. Kolmkeelsed kõnelejad lükivad väljendusse korraga elemente kolmest keelest. Seejuures haaratakse kõiki grammatilisi valdkondi: foneetikat, fonoloogiat, süntaksit (ühildumist, sugu) jne (Clyne 1997: 107-111).

(11) Kuna koolilaagri jooksul ollakse vahel ka klassiruumis (kui nt vihma sajab), siis on reegel, et iga päev töötavad korrapidajad (pühivad põranda puhtaks, teevad tahvli puhtaks jne). Kord toimus järgmine vestlus õpetaja (Õ) ja laste vahel. (Kohtla-Järve Pärna Põhikool, 3. klass, juuni 2004.) Õ: Так, кто сегодня у нас дежурный? 'Nii, kes on täna korrapidaja?' Т1: Сегодня kes on on duty? 'Kes on täna korrapidaja?' P1: Сергей. 'Sergei.'

Üsna levinud on kolmkeelsed salmikesed, lapsed lükivad neisse eesti, vene või inglise keele sõnu nii, et kõlaks luuletuse moodi.

(12) One, two, korraga. Полна taldrik творога. 'Üks, kaks, korraga. Taldrik on kohupiima täis.' 


\subsection{Kahe või ühe keele sarnaste sõnadega mäng}

Eesti ja vene keeltes on kahtlemata olemas hulk sarnase hääldusega sõnu (ра·lavik - полови•к 'põrandariie', ko·rrusel - карусе·ль 'karrussell') ehk kakskeelseid homofoone, mis kuuluvad ühelt keelelt teisele üleminekut - M. Clyne’i (2003: 168) terminoloogias transversiooni - hõlbustavate tegurite hulka. Selliseid sõnu kasutatakse meelega just huumori efekti taotledes. Üsna tihti pannakse kokku eestikeelseid sõnu, mis on osalised homofoonid. Näiteks sõna looma+maja levitamisel võetakse tüvesid liitsõnadest looma+aed ja loome+maja ning luuakse täiesti uus sõna, mille venekeelne vaste oleks дом животного. Tegelikult ei mängi siin tähendus mingit rolli, vaid tahetakse lihtsalt uue naljaka liitsõnaga oma keelelisi oskusi demonstreerida.

\section{Tsitaat}

Tsitaadid kohtuvad kogutud andmetes sageli. Tsitaadi keel jääb selliseks, milline see antud situatsioonis oli. On arusaadav, et otsekõne või tsitaat on eesti keeles, kui seda kasutab eestikeelne kõneleja, nagu näites (13) eesti keele õpetaja.

(13) Poisid (P1, P2, P3) tahavad jalgpalli mängida, kuid ei leia palli. Hakkavad seda otsima. Õpetaja (Õ) tuleb appi. (Kohtla-Järve Pärna Põhikool, juuni 2003, 3. klass.)

P1: Где мяч? Мы же вчера играли. 'Kus on pall? Me mängisime ju eile.'

Р2: Я не знаю. 'Ma ei tea.'

P1: Куда ты его положил? 'Kuhu sa selle panid?'

Õ: Kas see võib kapis olla? 'Kas see võib kapis olla?'

P1: Oŭ, нашёл! Aitäh! 'Ohoo, leidsin!'

P3 (astub klassi): Нy? Где он был? 'Noh? Kus see oli?'

P1: B kapis! 'Kapis!'

Näites 13 tsiteerib P1 oma õpetajat. Kui õpetaja oletab eesti keeles, et pall võib olla kapis, siis vastates oma partnerile ( $\left.\mathrm{P}_{3}\right)$ kasutab $\mathrm{P}_{1}$ eesti keelt. Kui aga õpetaja ettepanek aitab lastel palli leida, siis tänab P1 teda eesti keeles.

Vahel on väga raske aru saada, et laste sõnad reprodutseerivad kellegi poolt öeldut, nagu näites (14).

(14) Kaks poissi (P1 ja P2) tulevad kauplusest, käes saiakesed ja pudel vett. Kooliaeda sisenedes istuvad suurele palgile. (Kohtla-Järve Pärna Põhikool, 3. klass, juuni 2004.)

P1: Нет, ну ты и считаешь! У тебя, вообще, что с математикой? Девять, девять. А̀ kümme nelikümmend не хочешь? 'Oh sa poiss, küll sa arvutad! Kuidas on sul matemaatikaga lood? Üheksa, üheksa. Aga kümme nelikümmend ei taha?'

Võib oletada, et poisid plaanisid kaupluses vähem raha kulutada, kui välja tuli. See, et poiss ütleb hinna eesti keeles, näitab omakorda, et müüja võis olla eestlane ja et poes vesteldi (vähemalt osaliselt) eesti keeles, nii et tegemist võib olla 
tsitaadiga. Teine võimalik seletus on poisi taotlus, et tema sõnad kõlaksid autoriteetsemalt. Seepärast rõhutab ta hinda eesti keeles.

\section{Kvaasitõlge}

See funktsioon esineb siis, kui kõneleja kordab öeldut teises keeles, et oma sõnumit rõhutada, nagu näidetes (15) ja (16).

(15) Kaks tüdrukut (T1 ja T2) mängivad õues. Äkki märkab üks nendest, et on oma võtmed ära kaotanud. (Kohtla-Järve Pärna Põhikool, 3. klass, juuni 2004.)

Т1: Как я теперь домой попаду? Мамы до 8 не будет. 'Kuidas ma nüüd koju saan? Ema ei ole kella kaheksani.'

Т2: Не плачь! Мы их сейчас найдём. Всё будет нормально, tipp-topp!

‘Ära nuta! Küll me need nüüd leiame! Kõik saab korda, tipp-topp!'

Näites (15) kasutab kõneleja oma lohutussõnade paremaks mõjumiseks eestikeelset väljendit juba vene keeles öeldu kordamiseks.

Vahel korratakse vene keeles öeldut eesti keeles, et tähelepanu endale tõmmata, nagu näites (16).

(16) Üks tüdruk (T1) võtab oma seljakotist komme. Pakub ka oma pinginaabrile, kes istub midagi kirjutades (P1). (Kohtla-Järve Pärna Põhikool, 2. klass, juuni 2004.)

T1: Хочешь конфетку? 'Kas sa kommi tahad?'

P1 ei vasta

T1: Kihiline komm? 'Kihiline komm?'

P1: Kому? 'Kellele?'

Т1: Да тебя спрашиваю! Хочешь? 'Sinult ju küsin! Kas sa tahad?'

P1: Aza. 'Ahah.'

Näites (16) toimub koodivahetus pärast seda, kui tüdruk ei saa oma küsimusele vastust. Võib oletada, et ta kordab eesti keeles mitte ainult tähelepanu otsimise eesmärgil, vaid ka seepärast, et on lihtsam komme nimetada just nende vabrikumärgi järgi. Need "kihilised kommid" kõlavad vene keeles väga kohmakalt: слоёнъц конфеты. Peab arvestama ka sellega, et Kohtla-Järvel ollakse niivõrd harjunud toiduainete ja tarbekaupade eestikeelsete nimedega, et venekeelseid vasteid isegi ei pruugita teada. Seetõttu võib kõnelejale täiesti reaalselt võimalik vene ekvivalent veider tunduda. Samas ei saa välistada võimalust, et kõneleja tahab rõhutada, et see on just kihiline komm, mis on teistest kommisortidest maitsvam, kallim vms. 


\section{Teemavahetus}

Teemavahetust kohtab kogutud materjalis üllatavalt harva. Tavaliselt on see üks sagedamaid funktsioone (eriti siis, kui on selge meie-ja nende-kood (vt nt Gumperz 1982a) või kui on tegemist koodivaheldusega, s.o eri valdkondade keelekasutusega. Üheks põhjuseks võib siin olla see, et seni on õnnestunud fikseerida peamiselt lühivestlusi, kus ei ole jõutud mitut teemat arendada või vahetada.

Ühe teise uurimuse käigus, mille vaatlusalusteks olid samad suvise laagri algklassilapsed, on fikseeritud näide (17).

(17) Kaks poissi ( $\mathrm{P} 1$ ja P2) vestlevad omavahel veerandi lõpuhinnetest, selle käigus tulevad jutuks jõulud. (Kohtla-Järve Pärna Põhikool, 4. klass, detsember 2003.)

P1: Как оценки? 'Millised on hinded?'

P2: В норме. 'Normis'

P1: У тебя что в четверти по эстонскому? 'Mis on sul veerandis eesti keele eest?'

P2: Четыре. А у тебя? 'Neli. Aga sul?'

P1: Да, три. Теперь меня к бабушке на Чудское не отпустят на jõulud. 'Ah, kolm. Nüüd ei lasta mind jõuludeks vanaema juurde Peipsi äärde.'

P2: Дааа. Jõulud, päkapikud, piparid. Tore pidu! 'Jah. Jõulud, päkapikud, piparkoogid. Tore pidu!'

P1: Boт и uus aasta с книжкой, а не на järve. 'On alles uus aasta raamatuga, mitte järve ääres.'

P2: Ранъше надо было думать! 'Oleks pidanud varem mõtlema!'

Vestlus algab veerandihinnete arutamisest. Kui hakatakse jõule meenutama, tuleb kohe kasutusele ka eesti keel. Siiski ei saa täiesti kindel olla, et see on just teemavahetuse näide. Need lapsed on koolis õppinud eesti pühi. Jõulud ja uusaasta on mõisted, mis kõnelejate meelest erinevad vene vastavatest mõistetest.

Muutus vestluse keeles toimub ka kummagi partneri teadvustamata, nagu näites (18).

(18) Lapsed mängivad õues. Tuleb õpetaja ja kutsub neid lõunat sööma. Lapsed hakkavad kooli poole jooksma. Kaks tüdrukut (T1 ja T2) tulevad rahulikumalt ja vestlevad omavahel. (Kohtla-Järve Pärna Põhikool, 3. klass, juuni 2004.)

Т1: Интересно, что сегодня на обед. 'Huvitav, mida täna lounaks antakse' Т2: Только бы не макароны. Терпеть их не могу, да ещё в такую жapy. 'Ainult mitte makaronid. Ma ei kannata neid ja veel sellises palavuses.'

T1 (näeb tee peal lepatriinut): Смотри-ка lepatriinu! 'Ennäe, lepatriinu!' Mõlemad laskuvad kükki.

T2: Смотри, у lepatriinu 7 точечек. 'Vaata, lepatriinul on 7 täpikest.'

Lõunast räägivad mõlemad lapsed vene keeles. Siis aga sisestatakse vestlusesse juhuslikult nähtud putuka eestikeelne nimetus. 


\section{Osalejaskonna muutus}

Selles funktsioonis muudab vestluse keelt uus kõnepartner, nagu näites (19).

(19) Pärast koolilaagrit kavatsevad poisid (P1, P2, P3) laiali minna. (KohtlaJärve Pärna Põhikool, 2. klass, juuni 2003.)

P1: Ты сейчас куда? 'Kuhu sa praegu lдhed?'

$\mathrm{P} 2:$ В библиотеку, а что? 'Raamatukokku, aga mis siis?'

P1: Я думал, что вместе домой пойдём. 'Ma mõtlesin, et meie läheme koos koju.'

P3 (kuuleb, et jutt käib raamatukogust): Так. Это кто из вас тоже за raamatom? 'Nii. Kes teist läheb ka raamatu järele?'

P2: Mina-mina. 'Mina-mina'

Р3: Пошли тогда. 'Lähme siis'

Ühesõnalist koodivahetust võib vestluses esile kutsuda uus kaasvestleja, kes kasutab teatud eestikeelset sõna/väljendit oma tavalises sõnavaras, nagu näites (20).

(20) Lapsed (P1, P2, T1, T2) mängivad rannas. (Kohtla-Järve 3. Keskkooli suvine keelelaager, juuni 2000, lapsed on algklasside õpilased.)

P1: У меня руки совсем стали грязные. Даже кросы не одеть. 'Mul on nii mustad käed. Isegi botaseid ei saa jalga panna.'

P2: И у меня тоже. 'Ja minul ka.'

Т1: Надо сходить к учительнице и бумаги попросить, у неё всегда ecmъ. 'Tuleb minna õpetaja juurde ja (tualett)paberit tema käest paluda, tal on see alati olemas.'

T2 (näeb, et nende juurde tuleb $\mathrm{P}_{3}$ ): Илья, попроси рареra у Татьяны Ивановны. 'Ilja, küsi (tualett)paberit Tatjana Ivanovnalt.'

$\mathrm{P}_{3}$ : Ок. Вам рарета цзельй rulli или как? 'Ok. Kas teil on vaja (tualett)paberit terve rull või kuidas?'

P1: Оŭ, ну принеси, как дадут. Только быстрее давай! 'Tоо niipalju kui antakse. Ainult tee kiiremini!'

On täheldatud, et tihti põhjustavad rühmasiseses vestluses üleminekut vene keelelt eesti keelele lapsed või noored, kes õpivad eesti õppekeelega koolis.

\section{Kommentaar}

Näites (21) esineb venekeelses lauses eestikeelne kiilsõna.

(21) On reede. Poisid lepivad kokku, kas nad lähevad laupäeval jalutama või mitte. (Kohtla-Järve Pärna Põhikool, 3. klass, juuni 2004.)

P1: А я завтра еду в Нарву с командой. Мы там весъ день тренируемся. 'Mina sõidan homme koos meeskonnaga Narva. Meie teeme seal kogu päeva trenni.'

P2: Aга, tähendab, нет. Ну ладно, а в воскресенье? 'Ahhaa, tähendab, ei. Olgu, aga pühapäeval?' 
P1: Давай, я завтра тебе позвоню. 'Teeme nii, ma helistan sulle homme.'

P2: Хорошо. 'Hästi.'

Kiilsõna tähendab kattub oma tähenduse poolest vene sõnaga значит. Poiss võinuks kogu lause vabalt ka vene keeles öelda.

Kiilsõna võib esineda ka pöördumise vormis, nagu näites (22).

(22) Suvise koolilaagri jooksul töötavad koolis erinevad huviringid. Mõned lapsed käivad tikkimas. Ühel päeval pöördub poiss (P1), kel tikkimine eriti ei õnnestu, eesistuva tüdruku poole. (Kohtla-Järve Pärna Põhikool, 2. klass, juuni 2004.)

P1: Kuule, покажи, как ты этот шов закрепляешь? [vaatab] Как у тебя красиво! 'Kuule, näita, kuidas sa selle õmbluse kinnitad?' [vaatab] 'Kui ilus sul on!'

On teada, et pöördumine Kuule! ei ole eriti viisakas ei eesti ega ka vene keeles. Oleks palju sobivam pöörduda tüdruku poole tema eesnime järgi. Näite oletuslik seletus on see, et eestikeelne sõnavorm on niivõrd kivistunud poisi keelekasutuses, et ta ei taju enam selle kõnekeelset varjundit. On võimalik ka see, et õpilane soovib demonstreerida oma eesti keele oskust. Selleks et tema sõnu võtaks kuulaja tõsisemalt, algab ta oma pöördumist just eestikeelsest väljendist.

Näites (23) kasutatakse koodivahetust vestlusteemast kõrvale põigates.

(23) Kaks poissi (P1 ja P2) vestlevad omavahel emade sünnipäevadest. (Kohtla-Järve Pärna Põhikool, 4. klass, juuni 2004.)

P1: Ты что маме на день рождения даришь? ‘Mida sa oma emale sünnipäevaks kingid?'

P2: Три розы. 'Kolm roosi.'

P1 (ümiseb vaikselt): Roosid, valged roosid .. [paus] .. А я вот не знаю чmo. 'Roosid, valged roosid... [paus] ... Aga mina ei tea, mida.'

P2: Да цветы всегда нормально. 'Lilled sobivad alati.'

Kõrvalmärkuse allikas võib olla laul "Valged roosid”. Seda laulu võis laps kuulda kas tunnis või mujal (näiteks raadios).

\section{Ekspressiivne funktsioon}

Lisaks mitteverbaalsele suhtlusele vahendavad vene emakeelega lapsed tundeelamuslikku informatsiooni vene-eesti koodivahetust kasutades. Ekspressiivne funktsioon esineb erinevate emotsioonide rõhutamiseks: siia kuuluvad nii rõõm kui ka kurbus, nii viha ja halb tuju kui ka imestus ja viisakus jne. Taoline koodivahetus hõlmab lingvistiliselt huvitavaid nähtusi ja annab infot kaasvestlejate emotsionaalse seisundi, hoiakute, teineteisesse suhtumise jms kohta. Koodivahetuse kaudu väljendatakse näiteks viha. 
(24) Üks poiss (P1) seisab klassis. Seljas on tal kapuutsiga jope. Teine (P2) hiilib talle seljatagant ligi ja äkiliselt paneb talle kapuutsi pähe. Esimene poiss pöördub vihaselt tahapoole. (Kohtla-Järve Pärna Põhikool, 2. klass, juuni 2004.)

P1: Tы что loll? 'Kas sa oled loll või?'

P2: Сам такой! 'Ise oled!'

Näites (24) toimub lolliks nimetamine eesti keeles, kusjuures solvaja vastab sellele nii, nagu oleks see tavaline vene nimisõna. See on küllap tavaline nähtus, et sõimatakse võõrkeeles. Teise keele kasutamine tundub ekspressiivsem.

Eesti sõnadega ropendavad ka vanemad kooliõpilased: nt pidur (väga aeglase arusaamisega inimese kohta), idiootik (hääldatakse just eesti moodi, mitte nii nagu vene keeles uдuom 'idioot'), debiilik (tavaliselt nende kohta, kes ei kuulu just meie-rühma). Ka halva enesetunde kirjeldamiseks võidakse valida eesti keelt, nagu näites (25).

(25) Kaks tüdrukut (T1 ja T2) vestlevad omavahel klassis. (Kohtla-Järve Pärna Põhikool, 3. klass, juuni 2004.)

Т1: Ты чего сегодня такая злая? 'Miks sa oled täna nii vihane?'

Т2: Ничего! Я haige u magamat' хочу. 'Mitte midagi. Mina olen haige ja tahan magada.'

Näites (26) aitab koodivahetus väljendada imestust.

(26) Kaks poissi (P1 ja P2) kavatsevad koju minna. Panevad oma asju seljakottidesse. Äkki võtab P2 taskust 25 krooni. (Kohtla-Järve Pärna Põhikool, 2. klass, juuni 2004.)

P1: Откуда у тебя такой raha? 'Kust on sul nii palju raha?'

P2: Это мне бабушка дала. 'Vanaema andis mulle.'

P1: Это по какому поводу? 'Mispärast?'

P2: Ну это папина мама из Тарту. Она редко приезжает. Вот и дала мне на “что-нибудь вкусненькое". Теперь думаю, что купить. 'Seе on isa ema Tartust. Ta tuleb siia harva. Niisiis andiski mulle, et ma ostaks “midagi magusat”. Nüüd mõtlen, mida osta.'

P1: Ого, здорово! А мне так много ещё никогда не дарили. 'Lahe! Mulle ei ole nii palju veel kunagi antud.'

Algklassi õpilase jaoks on 25 krooni suur raha. Arvatavasti tahab poiss just koodivahetuse kaudu oma hämmastust väljendada. Seejuures eestikeelne sõna raha on seostatud vene lausestruktuuriga.

Kord mõjus artikli autorile õpilase ootamatu imestunud rõõmuhüüe lausa rabavalt (27).

(27) Tulles ühel kenal päeval Võsule (Lahemaa rahvuspargis) ja jalutades seal mööda tänavat, tabas õpetajaid ehmatus. Üks esimeste "uurijate" (selliseid lapsi leidub alati igas rühmas, neile meeldib ette kiirustada ja siis naastes jutustada oma õpetajale midagi põnevat) seas jooksev poiss karjus (P1) kõvasti:

P1: Oго, там meri! 'Ohoo, seal on meri!' 
Tekkis mulje, et kuskil tänava lõpus jalutas president Lennart Meri ja õpilased tormasid sinna. Ôpetajad aga hakkasid muretsema, kuidas siis lapsed käitusid ja kuidas kord taastada. Nooremad õpetajad jooksid laste järele ja nende üllatuseks selgus, et tänav viis hoopis mere äärde. Sealt avanes väga kaunis merevaade. Kui kõik rahunes, siis üks õpetaja ikka küsis, mis põhjustas nii suurt imestust ja poiss vastas, et но это же море! 'see on ju meri!'.

\section{Personaliseerimine}

Seda funktsiooni kasutatakse juba põhikooli vanemates klassides.

(28) Autor (A) vestleb ühe oma teismelise tuttavaga (T):

A: Я твою сестру всё лето не видела. Где она была?'Ma ei ole sinu õde kogu suve jooksul näinud. Kus ta oli?'

T: Так она Tartus, menерь tudeng. 'Tema on ju Tartus, nüüd on ta tudeng.'

A: Ах да, она же гимназию закончила уже. Ну и теперь arst будет? 'Jah-jah, ta on ju gümnaasiumi juba lõpetanud. Kas ta saab nüüd arstiks?'

Т: Ну да, она об этом сама давно мечтала, и мама с папой так хотели. Только из неё arst... 'Jah, ta oli ju sellest juba ammu unistanud, ka ema isaga tahtsid seda. Ainult on ta selline arst...'

Koodi vahetatakse konkreetsele inimesele viidates. Vend soovib rõhutada, et õe sotsiaalne staatus on nüüd muutunud: koolitüdrukust on saanud Tartu Ülikooli üliõpilane. Tema kaasvestleja aktsepteerib seda ning ka tuleviku ameti kohta küsib just eesti keeles.

\section{Kokkuvõte}

Artiklis on käsitletud kaheksat vene-eesti koodivahetuse pragmaatilis-konversatsioonilist funktsiooni, mis esinevad Kohtla-Järve vene emakeelega laste igapäevastes vestlustes: keelemäng, tsitaat, kvaasitõlge, teemavahetus, osalejaskonna muutus, kommentaar, ekspressiivne funktsioon, personaliseerimine. Neid on analüüsitud P. Aueri (1995) mudelist lähtudes, mis käsitleb koodivahetust eelkõige kui kakskeelse suhtluse loomulikku osa.

Üldiselt toimuvad vahetused lause piirides, on valdavalt üksiksõnalised ja toimivad kontekstualiseerimisvihjena.

Kohtla-Järve venekeelsete noorte vene-eesti koodivahetuse süstemaatilist uurimist on vaja jätkata. Ainuüksi keelelise käitumise vaatlusest ei piisa, on vaja lindistada loomulikku suulist keelt grupiintervjuus (kui vestelda korraga mitme inimesega, siis tuleb pragmaatiliste funktsioonide seas paremini esile ka osalejaskonna muutus) ning uurida seda vestlusanalüüsi abil. Edasisi hüpoteese on veel ennatlik püstitada, kuid vaieldamatult toob keelematerjali kogumine ja uute näidete lisandumine muutusi koodivahetuse funktsioonide järjestusse.

Lõpetuseks olgu rõhutatud, et pragmaatilis-konversatsioonilist lähenemist ei või vaadelda ainuüksi mustvalgel printsiibil teatud lahtrisse jaotatava vestluse käsitlusena. 


\section{Kirjandus}

Álvarez, Ana I. 1979. Code-Switching Among Bilingual Children. University of Massachusetts, Amherst. [Käsikiri.]

Appel, René; Muysken, Pieter 1992. Language Contact and Bilingualism. London, New York, Melbourne, Auckland: E. Arnold a division of Hodder \& Stroughton.

Arnfast, Juni Söderberg; J. Normann Jørgensen 2003. Code-switching as a communication, learning, and social negotiation strategy in first-year learners of Danish. International Journal of Applied Linguistics 13 (1), 23-53.

Auer, Peter 1984. Bilingual Conversation. Amsterdam/Philadelphia: John Benjamins.

Auer, Peter 1992. Introduction: John Gumperz's approach to contextualization. - The Contextualization of Languages. Ed. by P. Auer, A. di Luzio. Amsterdam/Philadelphia: John Benjamins, 1-38.

Auer, Peter 1995. The pragmatics of code-switching: a sequential approach. - One Speaker, Two Languages: Cross-Disciplinary Perspectives on Code-Switching. Ed. by L. Milroy, P. Muysken. Cambridge: Cambridge University, 115-135.

Auer, Peter 1998. Introduction: Bilingual Conversation revisited. - Code-switching in Conversation. Language, Interaction and Identity. Ed. by P. Auer. London and New York: Routledge, 1-24.

Auer, Peter 1999. From codeswitching via language mixing to fused lects: towards a dynamic typology of bilingual speech. - International Journal of Bilingualism 3/4, 309-332.

Baker, Colin 1995. Foundations of Bilingual Education and Bilingualism. Clevedon, Philadelphia, Adelaide: Multilingual Matters.

Blom, Jan-Petter; Gumperz, John 1972. Social meaning in linguistic structures: codeswitching in Norway. - Directions in Sociolinguistics. Ed. by J. Gumperz, D. Hymes. New York: Holt, Rinehart and Winston, 407-434.

Clyne, Michael 1967. Transference and Triggering. The Hague: Martinus Nijhoff.

Clyne, Michael 1997. Some of the things trilinguals do. - International Journal of Bilingualism 1 (2), 95-116.

Clyne, Michael 2003. Dynamics of Language Contact. English and Immigrant Languages. Cambridge University.

Duranti, Alessandro 1991. Four properties of speech-in-interaction and the notion of translocutionary act. - Pragmatics at Issue. Selected Papers of the International Pragmatics Conference. Antwerp, August 17-22, 1987. Vol. 1. Pragmatics \& beyond. New series 6/1. Ed. by J. Verschueren. Amsterdam/Philadelphia: John Benjamins, 133-150.

Duranti, Alessandro; Goodwin, Charles 1993. Rethinking context: an introduction. Rethinking context. Language as an Interactive Phenomenon. Studies in the Social and Cultural Foundations of Language 11. Ed. by A. Duranti, Ch. Goodwin. Cambridge: Cambridge University, 1-42.

Ervin-Tripp, Susan M. 1964. An analysis of the interaction of language, topic and listener. - American Anthropologist 66 (6, Part 2), 86-102.

Ervin-Tripp, Susan M. 2001. Variety, style-switching, and ideology. - Style and Variation. Ed. by P. Eckert, J. Rickford. New York: Cambridge University, 44-56.

Fantini, Alvino E. 1985. Language Acquisition of a Bilingual Child: A Sociolinguistic Perspective. San Diego, CA: College-Hill.

Færch, Claus; Haastrup, Kirsten; Phillipson, Robert 1984. Learner Language and Language Learning. Multilingual Matters 14. Clevedon.

Fishman, Joshua A. 1965. Who speaks what language to whom and when? - La Linguistique 2, 67-88.

Genesee, Fred 2002. Portrait of the bilingual child. - Perspectives on the L2 User. Ed. by V. Cook. Clevedon: Multilingual Matters, 170-196. 
Genesee, Fred; Boivin, Isabelle; Nicoladis, Elena 1996. Talking with strangers: A study of bilingual children's communicative competence. - Applied Psycholinguistics 17, 427-442.

Genishi, Celia 1976. Rules for Code-Switching in Young Spanish-English Speakers: An Exploratory Study of Language Socialization. Berkeley: University of California. [Käsikiri.]

Grosjean, François 1982. Life with Two Languages. An Introduction to Bilingualism. Cambridge, Mass., and London, England: Harvard University.

Gumperz, John J. 1964. Linguistic and social interaction in two communities. - American Anthropologist 66 (6, Part 2), 137-154.

Gumperz, John J. 1967. On the linguistic markers of bilingual communication. - Journal of Social Issues 23, 48-57.

Gumperz, John J. 1973. The communicative competence of bilinguals: some hypotheses and suggestions for research. - Language in Society 2 (1), 143-154.

Gumperz, John J. 1982a. Discourse Strategies. Cambridge: Cambridge University Press.

Gumperz, John J. 1982b. Language and Social Identity. Cambridge: Camridge University Press.

Gumperz, John J. 1993. Contextualization and understanding. - Rethinking Context. Ed. by A. Duranti, C. Goodwin. Cambridge: Cambridge University, 229-252.

Gumperz, John; Hernández-Chavez, Eduardo 1975. Bilingualism, bidialectalism, and classroom interaction. - Functions of Language in the Classroom. Ed. by C. Cazden, V. P. John, D. Hymes. New York: Teachers College, 84-107.

Halmari, Helena; Smith, Wendy 1994. Code-switching and register shift: evidence from Finnish-English child bilingual conversation. - Journal of Pragmatics 21 (4), 427445 .

Herbert, Robert K. 2001. Talking in Johannesburg: the negotiation of identity in conversation. - Codeswitching Worldwide II. Ed. by R. Jacobson. Berlin, New York: Mouton de Gruyter, 223-249.

Jørgensen, J. Normann 1998. Children's acquisition of code-switching for power-wielding. - Code-Switching in Conversation. Language, Interaction and Identity. Ed. by P. Auer. London and New York: Routledge, 237-261.

Kalliokoski, Jyrki 1989. Ja. Rinnastus ja Rinnastuskonjunktion Käyttö. Suomalaisen Kirjallisuuden Seuran Toimituksia 497. Helsinki.

Kalliokoski, Jyrki 1995. Koodinvaihto ja keskustelun moniäänisyys. - Virittäjä 99, 2-24.

Koziol, Jessica Marie 2000. Code Switching Between Spanish and English in Contemporary American Society. http://www.smcm.edu/aldiv/ilc/pdfdocs/koziol.pdf (16.03.2006).

Le Page, Robert B.; Tabouret-Keller, Andrée 1985. Acts of Identity: Creole-based Approaches to Ethnicity and Language. Cambridge: Cambridge University Press.

Li, Wei 1995. Code-switching, preference marking and politeness in bilingual crossgenerational talk: examples from a Chinese community in Britain. - Journal of Multilingual and Multicultural Development 16/3, 197-214.

McClure, Erica 1981. Formal and functional aspects of the code switched discourse of bilingual children. - Latino Language and Communicative Behaviour. Ed. by R. P. Duran. Norwood, NJ: Ablex, 69-84.

McClure, Erica; McClure, Malcolm 1988. Macro- and micro-sociolinguistic dimensions of codeswitching in Vingard. - Codeswitching: Anthropological and Sociolinguistic Perspectives. Ed. by Monica Heller. Berlin: Mouton de Gruyter \& Co, 25-51.

Muysken, Pieter 2000. Bilingual Speech. A Typology of Code-Mixing. Cambridge: Cambridge University.

Myers-Scotton, Carol 1993. Social Motivations for Codeswitching: Evidence from Africa. Oxford: Oxford University. 
Plotnicov, Leonard; Silverman, Myrna 1990. Jewish ethnic signalling: social bonding in contemporary American society. - American Culture: Essays on the Familiar and the Unfamiliar. Ed. by Leonard Plotnicov. Pittsburgh: University of Pittsburgh, 89-110.

Poplack, Shana 1980. "Sometimes I'll start a sentence in English Y TERMINO EN ESPAŇOL": towards a typology of code-switching. - Linguistics 18, 7/8, 581-618.

Poplack, Shana 1988. Contrasting patterns of code-switching in two communities. Codeswitching: Anthropological and Sociolinguistic Perspectives. Ed. by Monica Heller. Berlin: Mouton de Gruyter, 215-244.

Rannut, Ülle 2003. Muukeelsete õpilaste integreerimine eesti koolis. Õpik kõrgkoolile ning muukeelsete õpilastega töötavale aine- ja klassiõpetajale. Tallinn: TPÜ.

Reyes, Iliana 2001. The Development of Grammatical and Communicative Competence in Bilingual Spanish Speakers. Berkeley: University of California. [Käsikiri.]

Romaine, Suzanne 2000. Bilingualism. Merton College, University of Oxford: Blackwell.

Stroud, Christopher 1998. Perspectives on cultural variability of discourse and some implications for code-switching. - Code-switching in Conversation. Language, Interaction and Identity. Ed. by P. Auer. London and New York: Routledge, 321-348.

Zabrodskaja, Anastassia 2004. Eesti keelt õppiv Kohtla-Järve vene koolide muukeelne laps. - Keel ja Kirjandus 11, 841-853.

Zabrodskaja, Anastassia (ilmumas). Muukeelsete algkoolilaste vene-eesti/eesti-vene koodivahetus Kohtla-Järvel. - Proceedings of the Annual Finnish and Estonian Conference of Linguistics. Finest Linguistics. Ed. by K. Kerge, M.-M. Sepper. Tallinn, May 6-7, 2004. Tallinn: TLÜ.

Zentella, Ana Celia 1982. Code-switching and interaction among Puerto Rican children. Spanish in the United States: Sociolinguistic Aspects. Ed. by J. Amastae, L. EllasOlivares. Cambridge: Cambridge University, 354-385.

Zentella, Ana Celia 1997. Growing up Bilingual: Puerto Rican Children in New York. Maiden, MA: Blackwell.

Vseviov, David 2002. Kirde-Eesti urbaanse anomaalia kujunemine ning struktuur pärast teist maailmasõda. Tallinna Pedagoogikaülikool. Humanitaarteaduste dissertatsioonid 8. Tallinn: TPÜ Kirjastus.

Weinreich, Uriel 1966. Languages in Contact: Findings and Problems. Fourth Printing. The Hague: Mouton.

Wierzbicka, Anna 1999. Emotions Across Languages and Cultures. Diversity and Universals. Paris: Cambridge University. 


\section{THE CONVERSATIONAL FUNCTIONS OF RUSSIAN-ESTONIAN CODE-SWITCHING AMONG RUSSIAN-SPEAKING CHILDREN IN KOHTLA-JÄRVE}

\section{Anastassia Zabrodskaja}

The object of the present research is multilingual communication among Russian-speaking children with a special focus on Russian-Estonian code-switching patterns during the bilingual discource. The study is based on data collected in different everyday situations.

The code-switching data is analysed from the conversational point of view. The starting point of such approach is that code-switching is a conversational event which has, first and foremost, conversational functions (Auer 1984, 1992, 1995, 1998, 1999).

The results demonstrate that the classical conversational functions are well represented in the data: language play (puns etc.), reported speech, reiterations, topic shift, change of participant constellation, parentheses or side-comments, expressive function, personalization. Code-switching serves as a contextualisation clue and switches usually take place at clause boundaries.

The expressive function and language play are present in the data to a great extent. The language of the reported speech is often the same as it was in the situation described by the child. Thus, the quotations are usually in Estonian when describing a situation with an Estonian-speaking person. Code switches as reiterations are also often used for clarifying, emphasising or amplifying a message. Switching when changing topic is very rare in the data. Code-switching may also serve to mark the side-comments. This type of switch is rare but still observable in the data. Speakers personalize the message to talk about the issues that are of personal concern.

Children use different code-switching strategies without any conscious intention of signalling the bilingual identity.

Keywords: code-switching, discourse device, pragmatic-conversational model, pragmatic-conversational function, conversation analysis, Estonian, Russian

Anastassia Zabrodskaja (1981) on lõpetanud Tartu Ülikooli Narva Kolledži eesti keele teise keelena erialal. Kaitses magistrikraadi Tallinna Ülikoolis 2005. aastal eesti filoloogia alal. Alates 2005. aastast on Tallinna Ülikooli lingvistika doktorant ning töötab üld- ja rakenduslingvistika õppetooli juures. On uurinud keelekümblust, laste kakskeelsust ja vene-eesti koodivahetust. anastaza@tlu.ee 